Bull. Chem. Soc. Ethiop. 2018, 32(1), 53-63.

ISSN 1011-3924

(C) 2018 Chemical Society of Ethiopia and The Authors

Printed in Ethiopia

DOI: https://dx.doi.org/10.4314/bcse.v32i1.5

\title{
ADSORPTION OF BOVINE SERUM ALBUMIN ONTO ACTIVATED CARBON PREPARED FROM ELAEAGNUS STONE
}

\author{
Ünal Geçgel $^{1 *}$ and Osman Üner ${ }^{2}$ \\ ${ }^{1}$ Arda Vocational College, Trakya University, 22030 Edirne, Turkey \\ ${ }^{2}$ Department of Chemistry, Kırklareli University, 39020 Kırklareli, Turkey
}

(Received January 19, 2017; Revised March 4, 2018; Accepted March 26, 2018)

\begin{abstract}
In this study, the adsorption of bovine serum albumin was studied using the activated carbon prepared from Elaeagnus stone with chemical activation. Elaeagnus stone activated carbon was characterized using the point of zero charge, Fourier transform infrared spectra, Brunauer-Emmet-Teller method, scanning electron microscopy, and elemental analysis. The BET surface area of Elaeagnus stone activated carbon obtained by using $30 \% \mathrm{ZnCl}_{2}(\mathrm{w} / \mathrm{w})$ was determined to be $1588 \mathrm{~m}^{2} / \mathrm{g}$. The effects of adsorbent dosages, contact time, initial bovine serum albumin concentrations, temperature and $\mathrm{pH}$ on the adsorption were investigated. The optimum values of adsorbent dosage, $\mathrm{pH}$, and contact time were determined to be $1 \mathrm{mg} / \mathrm{mL}, 5$, and $160 \mathrm{~min}$ for $500 \mathrm{mg} / \mathrm{L}$ BSA concentration, respectively. Additionally, the studies of adsorption equilibrium and kinetics were performed. The best fitting model from the experimental data was determined to be Langmuir model and the adsorption follows a pseudo-first-order kinetic model.
\end{abstract}

KEY WORDS: Elaeagnus stone, Bovine serum albumin, Adsorption, Activated carbon

\section{INTRODUCTION}

Activated carbon is one of the mostly preferred industrial adsorbents in many different applications, such as medical treatment, filtration and purification, catalysts, and electrode materials in electrochemical devices [1-5]. The reasons for the common usage of the activated carbon in adsorption processes are variable characteristics of surface chemistry, well-developed internal pore structure, and its high specific surface area [6-7].

Activated carbon is generally obtained with two methods which are physical and chemical activations. Chemical activation has more significant advantages compared to physical activation, such as a single step in manufacturing activated carbon, low cost, higher yields and greater active surface area [8-11].

Adsorption method is widely used in the removals of contaminants from aqueous solutions [12-17]. The adsorption process in which activated carbons are used is operative, but its applications are limited due to the high production costs of activated carbons [18]. In order to produce low cost activated carbon, many researchers have utilized agricultural wastes, such as walnut shell, almond shell, hazelnut shell, apricot stone [19], pine cone [20], coconut shell, groundnut shell and bamboo dust [21], pea shell [22], pistachio shell [23], Pomegranate wood [24]. Therefore, the activated carbon (EAC) produced from waste Elaeagnus stone with chemical activation method was used for bovine serum albumin (BSA) adsorption.

BSA is a globular protein, and approximately $52-62 \%$ of total plasma protein fraction is represented by the blood plasma protein [25]. For biological systems, BSA is a very significant protein in terms of osmotic blood pressure [26], transportation [27] and maintenance of blood $\mathrm{pH}$ [28]. The protein adsorptions on activated carbon are very significant for low cost and efficiency, and there is an important role in its related areas, such as new biocatalysts and protein purification for medicine, analytical chemistry and pharmacology [29]. Therefore, the performance of obtained EAC was examined with respect to BSA removal from aqueous

*Corresponding author. E-mail: unalgecgel@trakya.edu.tr

This work is licensed under the Creative Commons Attribution 4.0 International License 
solution, and the effects of initial BSA concentration, contact time, temperature, adsorbent dosage, and $\mathrm{pH}$ on the adsorption process were evaluated. Furthermore, BSA adsorption mechanism on the activated carbon was explained by using adsorption isotherms and kinetics.

\section{EXPERIMENTAL}

\section{Materials}

BSA (CAS number of 0009048468) used as an adsorbate was supplied by Sigma Aldrich. By dissolving the calculated amount of BSA powders in water (double-distilled), BSA stock solution was adjusted to $2000 \mathrm{mg} / \mathrm{L}$. Then, the diverse solutions with various concentrations were adjusted to serial dilutions between $500-1600 \mathrm{mg} / \mathrm{L}$. Phosphate buffer solution, $\mathrm{HCl}$ (CAS number of 0007647010) and $\mathrm{NaOH}$ (CAS number of 0001310732) were supplied by Sigma Aldrich.

\section{Preparation of activated carbon}

Powdered Elaeagnus stone $(10 \mathrm{~g})$ and $\mathrm{ZnCl}_{2}$ solutions with $30 \%(\mathrm{w} / \mathrm{w})$ were put in a flask for activation step. The mixture in this flask was boiled under reflux at around $85^{\circ} \mathrm{C}$ for $60 \mathrm{~min}$. After that the mixture was allowed to dry in petri dishes for $24 \mathrm{~h}$ at $105^{\circ} \mathrm{C}$ by using an incubator. At the carbonization step in which activation also occurs, dried mixture was baked at $600{ }^{\circ} \mathrm{C}$ for $60 \mathrm{~min} .0 .1 \mathrm{M} \mathrm{HCl}$ solution was used to treat the produced EACs for the elimination of zinc and chloride ions and contaminants on EAC surface, before EACs were rinsed with double-distilled water until $\mathrm{pH}$ became 7. Lastly, EACs were dried at $105{ }^{\circ} \mathrm{C}$ and they were milled and placed into brown bottles for other experiments.

\section{Characterization of prepared EAC}

Leco TrueSpec Micro model Elemental Analyzer was utilized to measure the raw material and EAC's $\mathrm{C}, \mathrm{H}, \mathrm{N}$ and $\mathrm{S}$ contents. The oxygen percentages in substances were determined by difference. By using Micromeritics TriStar II 3020, nitrogen $\left(\mathrm{N}_{2}\right)$ adsorption-desorption experiment were achieved at liquid nitrogen temperature $\left(-196.15^{\circ} \mathrm{C}\right)$. To remove volatile contaminations on surface, EAC sample was degassed at $90{ }^{\circ} \mathrm{C}$ for 30 minutes and at $300{ }^{\circ} \mathrm{C}$ for $120 \mathrm{~min}$ under vacuum before the measurement. The total volume was calculated through nitrogen adsorption at $\mathrm{P} / \mathrm{P}_{0}$ which is equal to 0.984 , and EAC surface area was determined by Brunauer-Emmet-Teller (BET) method. Also, Fourier transform infrared spectra (FTIR Perkin Elmer) have provided to determine surface functional groups onto EAC and scanning electron microscope (SEM; FEI-QUANTA FEG 250) has given information about EAC surface characteristics. The $\mathrm{pH}$ where the EAC surface has zero charge $\left(\mathrm{pH}_{\mathrm{PZC}}\right)$ was determined by the following procedure: $0.1 \mathrm{~g}$ EAC and $0.1 \mathrm{M} 50 \mathrm{~mL} \mathrm{KNO}_{3}$ solution were put into Erlenmeyer flasks. By adding 0.1 M NaOH or $\mathrm{HCl}$, the initial pHs of these Erlenmeyer flasks were adjusted between 2 and 11, separately. The final pHs were determined and plotted versus initial pHs, after 48 hour contact time by a shaker (WiseBath) with thermostat-controlled [30].

\section{Methods}

Using the batch method, adsorption experiments were achieved. After the adsorption process of BSA onto EAC, the solution was centrifuged at $4000 \mathrm{rpm}$ for $20 \mathrm{~min}$. The supernatant obtained from the centrifugation process was filtrated by means of a PVDF hydrophilic syringe filter with the pore size of $0.22 \mu \mathrm{m}$. By using the UV/Visible spectrophotometer (Mecasys Optizen POP Series), BSA concentrations were calculated at the wavelength of $280 \mathrm{~nm}$. 
Following mass balance equation was used to calculate the adsorbed BSA amount per unit mass of adsorbent $\left(q_{e}\right)$ :

$q_{e}=\frac{\left(C_{i}-C_{e}\right) V}{\mathrm{w}}$

and the adsorption percentage of BSA was determined by using the formula:

Adsorption $(\%)=\frac{\left(C_{i}-C_{e}\right)}{C_{i}} \times 100$

where $w$ is adsorbent mass $(\mathrm{g}), V$ is the volume of solution $(\mathrm{L}), C_{e}$ is the equilibrium concentration of BSA solution $(\mathrm{mg} / \mathrm{L})$, and $C_{i}$ is the initial BSA concentration $(\mathrm{mg} / \mathrm{L})$.

The effects of $\mathrm{pH}$, temperature, contact time, initial BSA concentration, and adsorbent dosage were experimentally studied as follows. To detect the optimum amount of the activated carbon, six separate BSA solutions, each of $500 \mathrm{mg} / \mathrm{L}$ and $25 \mathrm{~mL}$, were put into $100 \mathrm{~mL}$ conical flasks. Adding the activated carbon of $5,15,25,35,45$ and $55 \mathrm{mg}$ for each BSA solution, the adsorption process was performed at $100 \mathrm{rpm}$ by using a thermostatic shaking water bath after reaching thermal equilibrium at $25^{\circ} \mathrm{C}$.

To scrutinize the contact time and BSA concentration effects on BSA adsorption, the activated carbon of $25 \mathrm{mg}$ was added into BSA solutions of 500, 800,1000, 1200, 1600 and $2000 \mathrm{mg} / \mathrm{L}$ separately, and these BSA solutions were shaken until establishing the equilibrium of adsorption. For kinetic studies, BSA concentration in equilibrium was determined by taking the sufficient amounts from BSA solutions at determined time intervals.

To examine the temperature effect on BSA adsorption, at 15,25 and $35{ }^{\circ} \mathrm{C}$, the activated carbon of $25 \mathrm{mg}$ was separately added into $25 \mathrm{~mL}$ BSA solutions with the concentrations of $500-2000 \mathrm{mg} / \mathrm{L}$. After that, these solutions were shaken until establishing the equilibrium of adsorption. For each temperature, BSA concentration in equilibrium was determined.

Table 1. The adsorption and kinetic models used in this study and their parameters.

\begin{tabular}{|c|c|c|c|}
\hline Isotherm & Equation & Linearized form & Parameters \\
\hline \multirow{3}{*}{ Langmuir } & \multirow{3}{*}{$q_{e}=\frac{q_{m} K_{L} C_{e}}{\mathrm{q}+K_{L} C_{e}}$} & \multirow{3}{*}{$\frac{C_{e}}{q_{e}}=\frac{1}{q_{m} K_{L}}+\frac{C_{e}}{q_{m}}$} & $\begin{array}{l}q_{m}(\mathrm{mg} / \mathrm{g}): \text { Complete monolayer adsorption } \\
\text { capacity }\end{array}$ \\
\hline & & & $C_{e}(\mathrm{mg} / \mathrm{L}):$ The equilibrium concentrate \\
\hline & & & $\begin{array}{l}K_{L} \quad(\mathrm{~L} / \mathrm{mg}): \text { The Langmuir adsorption } \\
\text { constant }\end{array}$ \\
\hline \multirow[t]{2}{*}{ Freundlich } & \multirow[t]{2}{*}{$q_{e}=K_{F} C_{e}^{\frac{1}{n}}$} & \multirow{2}{*}{$\begin{array}{l}\ln q_{e} \\
=\ln K_{F}+\frac{1}{n} \ln C_{e}\end{array}$} & $\begin{array}{l}n \text { : The empirical parameter relating the } \\
\text { adsorption intensity, which varies with the } \\
\text { heterogeneity of material (dimensionless) }\end{array}$ \\
\hline & & & $\begin{array}{l}K_{F}\left(\mathrm{mg} \mathrm{g}^{-1} \mathrm{~L}^{1 / \mathrm{n}} \mathrm{mg}^{-1 / \mathrm{n}}\right) \text { : The Freundlich } \\
\text { adsorption constant }\end{array}$ \\
\hline \multirow{3}{*}{$\begin{array}{l}\text { Pseudo-first } \\
\text { order }\end{array}$} & \multirow{3}{*}{$\begin{array}{l}\frac{d q_{t}}{d t} \\
=k_{1}\left(q_{e}-q_{t}\right)\end{array}$} & \multirow{3}{*}{$\begin{array}{l}\log \left(q_{e}-q_{t}\right) \\
=\log q_{e}-\frac{k_{1} t}{2.303}\end{array}$} & $q_{t}(\mathrm{mg} / \mathrm{g}):$ The adsorption capacity at time $\mathrm{t}$ \\
\hline & & & $t(\min ):$ Contact time \\
\hline & & & $\begin{array}{l}k_{l}\left(\min ^{-1}\right): \text { The rate constant of pseudo-first } \\
\text { order adsorption }\end{array}$ \\
\hline $\begin{array}{l}\text { Pseudo- } \\
\text { second order }\end{array}$ & $\begin{array}{l}d q_{t} \\
=k_{2}\left(q_{e}-q_{t}\right)^{2}\end{array}$ & $\frac{t}{q_{t}}=\frac{1}{k_{2} q_{e}^{2}}+\frac{1}{q_{e}} t$ & $\begin{array}{l}k_{2}\left(\mathrm{~g} \mathrm{mg}^{-1} \min ^{-1}\right): \text { The rate constant of } \\
\text { pseudo-second order adsorption }\end{array}$ \\
\hline
\end{tabular}

To determine the optimal $\mathrm{pH}$ for the adsorption process of BSA onto the activated carbon in this study, $25 \mathrm{mg}$ of activated carbon was added into $25 \mathrm{~mL}$ BSA solutions with the concentration of $500 \mathrm{mg} / \mathrm{L}$. By using sodium phosphate buffer solution, $\mathrm{pH}$ of solution was adjusted to desired acidic and basic values adding the small amounts of $\mathrm{HCl}$ and $\mathrm{NaOH}$. The 
solution was shaken until establishing the equilibrium of adsorption. After that BSA concentration in equilibrium was determined. Moreover, Equilibrium and kinetic studies for BSA adsorption on EAC were investigated by using the equations given in Table 1 .

\section{RESULTS AND DISCUSSION}

\section{Characterization of EAC}

Table 2 shows the elemental contents of EAC and Elaeagnus stone. After activation and carbonization steps, the EAC carbon content considerably increased in comparison with Elaeagnus stone. As expected, the contents of hydrogen and oxygen displayed a reverse tendency. That is why; volatile compounds (i.e., oxygen and hydrogen) removed from the carbonaceous product because of Elaeagnus stone decomposition during carbonization and activation steps. Thus, the carbonaceous product had more carbon content.

Table 2. Contents of the raw material and EAC with impregnation ratio of $30 \%(w / w)$.

\begin{tabular}{|l|c|c|}
\hline Element & Raw material (wt.\%) & Activated carbon (wt.\%) \\
\hline Carbon & 46.96 & 70.10 \\
\hline Hydrogen & 6.564 & 2.091 \\
\hline Nitrogen & 1.690 & 2.354 \\
\hline Sulfur & 0.7933 & 0.8487 \\
\hline Oxygen (by difference) & 43.99 & 24.61 \\
\hline
\end{tabular}

The highest surface area of EAC was obtained as $1588 \mathrm{~m}^{2} / \mathrm{g}$. Also, the values of average pore diameter $(2.266 \mathrm{~nm})$, micropore volume $\left(0.0761 \mathrm{~cm}^{3} / \mathrm{g}\right)$, total pore volume $\left(0.8996 \mathrm{~cm}^{3} / \mathrm{g}\right)$, micropore area $\left(1139 \mathrm{~m}^{2} / \mathrm{g}\right)$, and BET surface area display that the produced EAC has a properly porous surface for adsorptions in which micropore areas of activated carbons are desired to have high values. Surface texture, fundamental physical properties and pore morphology of the adsorbent surface were characterized using scanning electron microscopy (SEM; FEI-QUANTA FEG 250). Figure 1 (a-b) displays SEM images of EAC surfaces. A great deal of pores and a heterogeneous texture with variable cavities were observed on EAC surfaces.
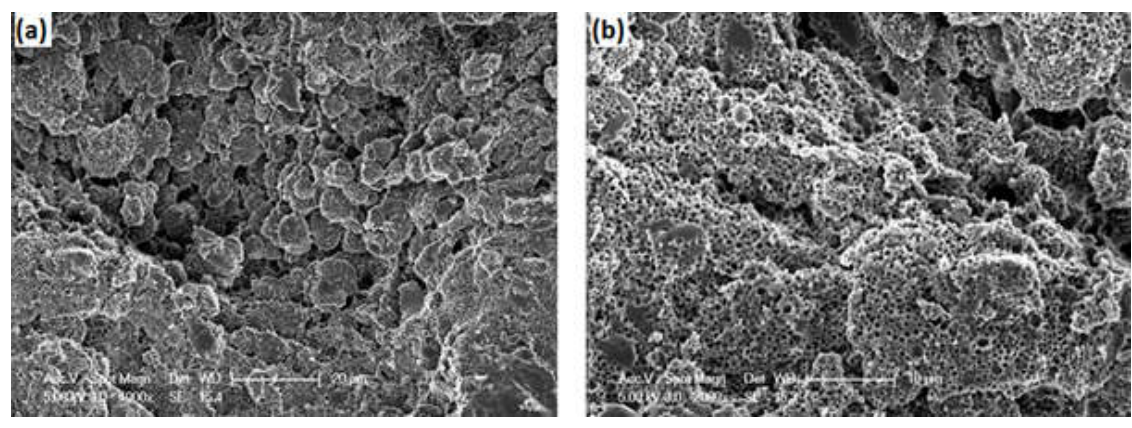

Figure 1. SEM images of raw material and EAC (a) 1000x and (b) 2000x.

Figure 2 presents FTIR spectra of EAC and Elaeagnus stone. As seen in the FTIR spectrum of raw material, an intense band at around $1028 \mathrm{~cm}^{-1}$ and the bands at $1239 \mathrm{~cm}^{-1}$ indicate the vibrations of $\mathrm{C}-\mathrm{O}$ stretching at ester, ether, phenols, or alcohols groups [31]. The two bands at 1456 and $1541 \mathrm{~cm}^{-1}$ belong to the vibrations of skeletal $\mathrm{C}=\mathrm{C}$ at aromatic rings and the bands at 
about 1376 and $1445 \mathrm{~cm}^{-1}$ are because of the vibrations of $\mathrm{C}-\mathrm{H}$ in-plane bending at methylene and methyl groups [32]. The band at $1614 \mathrm{~cm}^{-1}$ is due to olefinic $\mathrm{C}=\mathrm{C}$ stretching [33]. The band at $1744 \mathrm{~cm}^{-1}$ corresponds to carbonyl $\mathrm{C}=\mathrm{O}$ groups. The bands at 2854 and $2923 \mathrm{~cm}^{-1}$ display the vibrations of $\mathrm{C}-\mathrm{H}$ at methyl and methylene groups [34]. The wide absorption band between 3400 and $3200 \mathrm{~cm}^{-1}$ corresponds to the vibrations of N-H stretching and $\mathrm{OH}$ groups [35]. On the other hand, less adsorption bands are seen in EAC spectrum compared to the spectrum of raw material. This displays diverse functional groups existing in the spectrum of raw material disappear during activation and carbonization steps. The bands between 1035 and $1154 \mathrm{~cm}^{-1}$ are because of C-O stretching in esters, phenols, alcohols, and carboxyl acids [36], similarly as in the raw material spectrum.

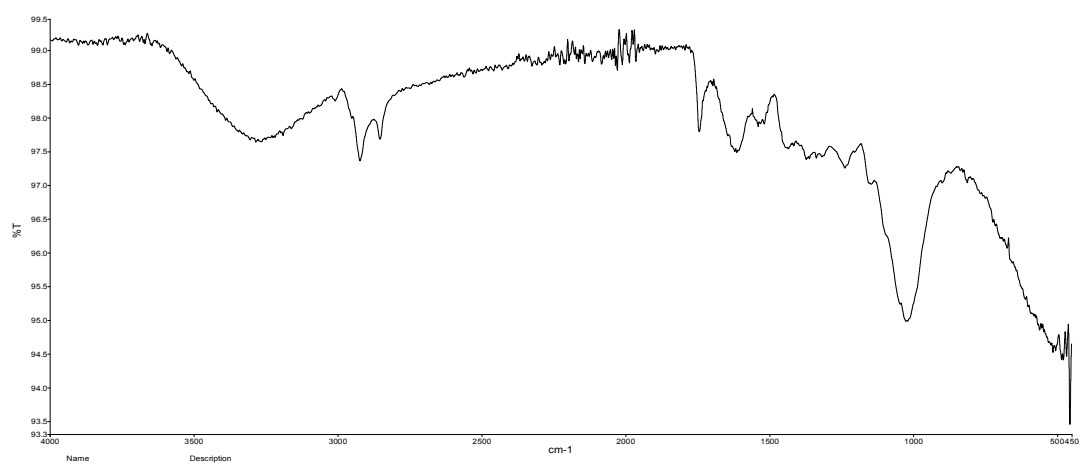

(a)

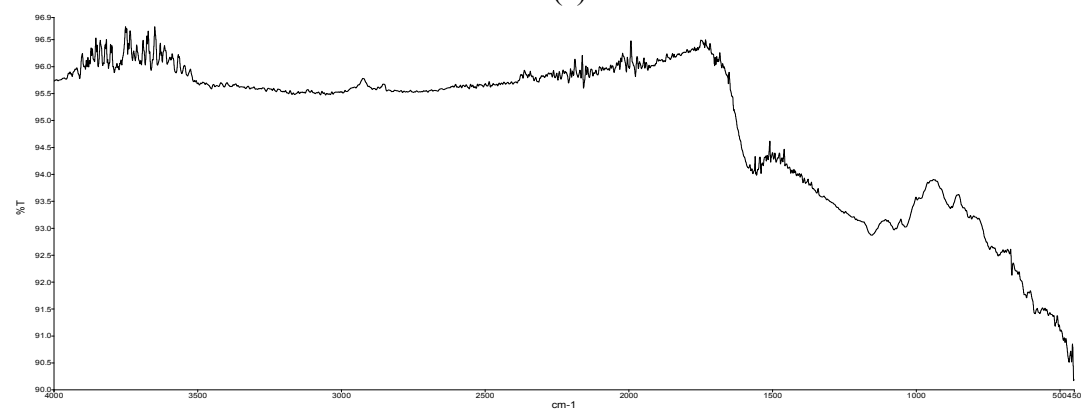

(b)

Figure 2. FTIR spectra of (a) raw material and (b) EAC.

$\mathrm{pH}_{\mathrm{PZC}}$ is accepted to be the value where final $\mathrm{pH}$ is equal to initial $\mathrm{pH}$ and the surface charge is neutral at $\mathrm{pH}_{\mathrm{PZC}}$ value. To realize interfacial properties, the $\mathrm{pH}_{\mathrm{PZC}}$ of an adsorbent is a significant characteristic. As shown in Figure 3, the value of $\mathrm{pH}_{\mathrm{PZC}}$ of $\mathrm{EAC}$ has been determined to be 7.05 .

\section{Effect of activated carbon dosage}

The relation between the dosages of activated carbon and BSA concentration adsorbed by the activated carbon is displayed in Figure 4. As shown in Figure 4, the percentage of BSA adsorption onto the activated carbon with the dosage at $1 \mathrm{mg} / \mathrm{mL}$ was found to be 98.43 . Also, it was observed that the adsorbed BSA amount slightly increased for the amount of the activated 
carbon with above the dosage at $1 \mathrm{mg} / \mathrm{mL}$. For this reason, the optimum adsorbent dosage was determined to be $1 \mathrm{mg} / \mathrm{mL}$.

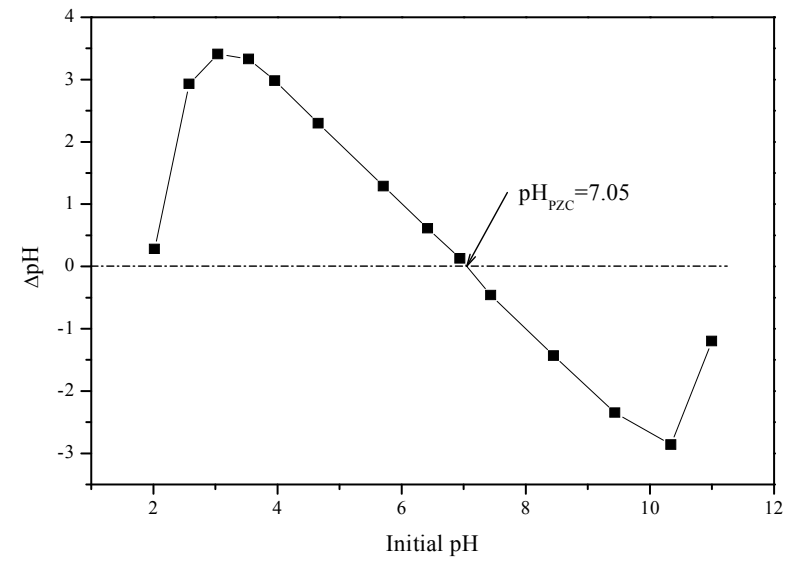

Figure 3. $\mathrm{pH}_{\mathrm{ZPC}}$ of EAC.

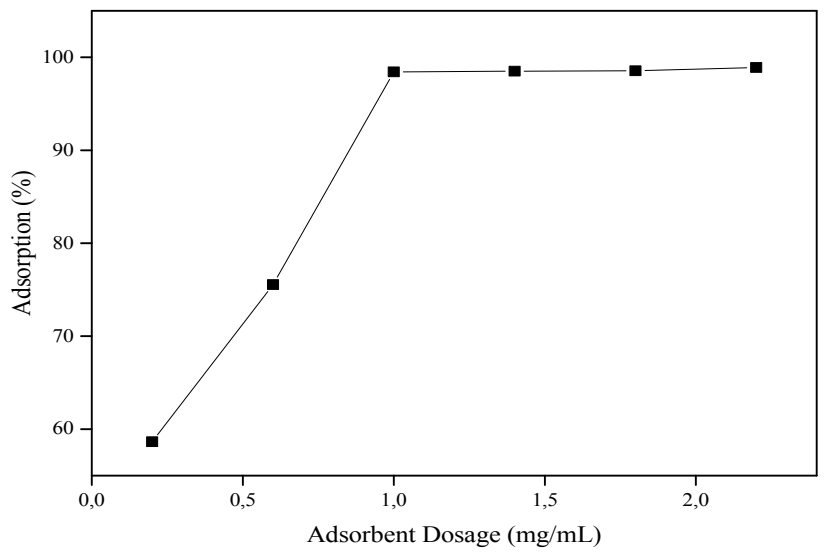

Figure 4. Effect of the adsorbent dosage on BSA adsorption $\left(\mathrm{C}_{\mathrm{i}}=500 \mathrm{mg} / \mathrm{L}, \mathrm{T}=25^{\circ} \mathrm{C}, \mathrm{pH}=5\right.$, shaking speed $=100 \mathrm{rpm}$ ).

\section{Effect of $p H$}

To determine the optimum $\mathrm{pH}$, BSA adsorption on activated carbon produced from Elaeagnus stone was studied at $\mathrm{pH}$ of $3,4,5,6,7,8$ and 9. As seen in Figure 5, the adsorption efficiency increased from $42.5 \%$ to $98.43 \%$ when the value of $\mathrm{pH}$ increased from 3 to 5 . Nevertheless, the adsorption efficiency decreased from $98.43 \%$ to $52.65 \%$ when the value of $\mathrm{pH}$ increased from 5 to 9 . The $\mathrm{pH}$ of aqueous solutions is an important parameter which has significant effects on adsorption processes. As a result, the optimum $\mathrm{pH}$ value for BSA adsorption onto EAC was found to be 5. It can be explained by the $\mathrm{pH}_{\mathrm{PZC}}$ value (7.05) for EAC due to the fact that the surface is charged positively at $\mathrm{pH}<\mathrm{pH}_{\mathrm{PZC}}$ whereas the surface is charged negatively at $\mathrm{pH}>$ $\mathrm{pH}_{\mathrm{PZC}}$. At the $\mathrm{pH}$ value of 5, the EAC surface is positively charged, while BSA surface is charged negatively because the isoelectric point of BSA is 4.7. The electrostatic attraction

Bull. Chem. Soc. Ethiop. 2018, 32(1) 
between the negatively charged BSA molecules and the positively charged EAC surface caused to be the maximum adsorption value at $\mathrm{pH}$ of 5 .

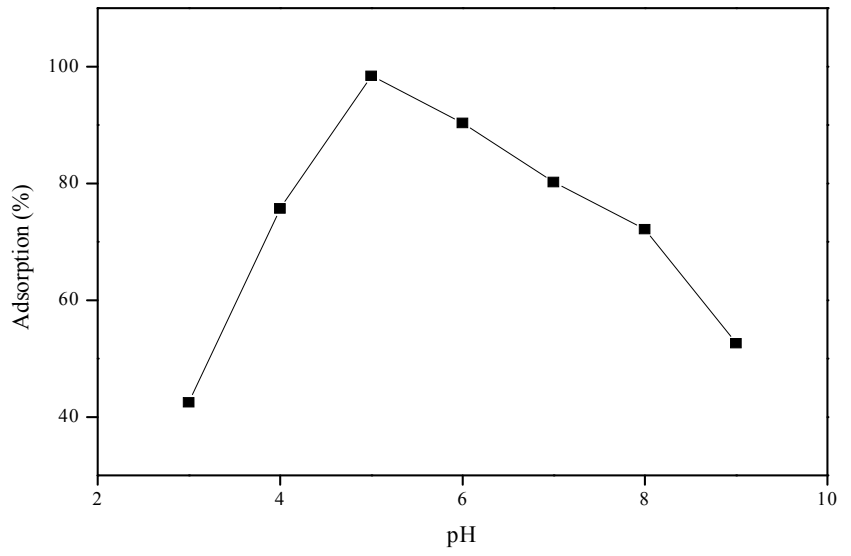

Figure 5. Effect of $\mathrm{pH}$ on BSA adsorption $\left(\mathrm{C}_{\mathrm{i}}=500 \mathrm{mg} / \mathrm{L}, \mathrm{EAC}\right.$ dosage $=1 \mathrm{mg} / \mathrm{mL}, \mathrm{T}=25^{\circ} \mathrm{C}$, shaking speed $=100 \mathrm{rpm})$.

\section{Effect of initial BSA concentration and contact time}

For different BSA concentrations $(500-2000 \mathrm{mg} / \mathrm{L})$, the change of adsorption on EAC with time is seen in Figure 6. As shown in Figure 6, the time for reaching the adsorption equilibrium is not identical for each initial BSA concentration. For instance, the time for reaching the equilibrium is $160 \mathrm{~min}$ for $500 \mathrm{mg} / \mathrm{L} \mathrm{BSA}$ concentration, while the time for reaching the equilibrium is 275 min for $2000 \mathrm{mg} / \mathrm{L}$ BSA concentration. Moreover, the adsorption at first occurs very fast, and it becomes slower in later times. This case can be explained that the active centrals on EAC are more available for adsorption at the initial times, and it becomes vice versa in later times. Additionally, the adsorption efficiency is lower at higher protein concentration $\left(C_{i} \geq 1200 \mathrm{mg} / \mathrm{L}\right)$ due to the electrostatic repulsion between the protein molecules in solution and the protein molecules on EAC surface.

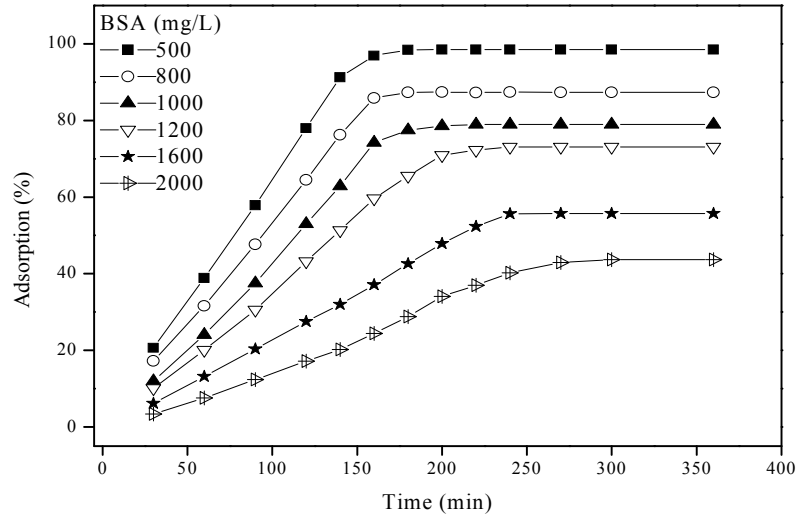

Figure 6. Effect of the initial BSA concentration and contact time $(\mathrm{EAC}$ dosage $=1 \mathrm{mg} / \mathrm{mL}, \mathrm{T}=$ $25^{\circ} \mathrm{C}, \mathrm{pH}=5$, shaking speed $=100 \mathrm{rpm}$ ). 
Effect of temperature

For the characterization of adsorption mechanism and the obtainment of high adsorption efficiency, one of the most important parameters is temperature. Therefore, as shown in Figure 7 , BSA adsorptions on EAC were conducted at 15,25 and $35^{\circ} \mathrm{C}$. The decrease at the values of adsorption was seen with the increase of temperature. Its reason can be explained by the increase of the kinetic energy of BSA molecules in solution along with the rise in temperature since the increasing kinetic energy caused the decrease of the interaction between EAC surface and protein molecules. Analogous trends have been presented by other researchers [37-38].

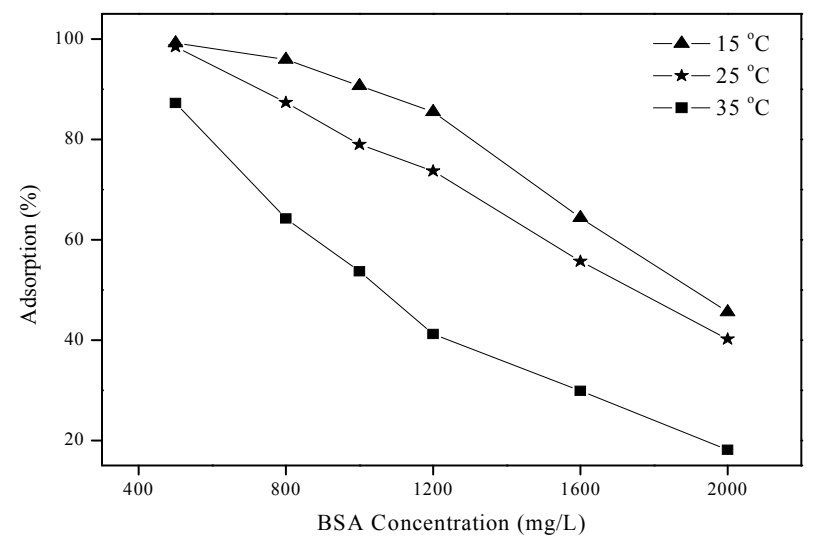

Figure 7. Effect of temperature $(\mathrm{EAC}$ dosage $=1 \mathrm{mg} / \mathrm{mL}, \mathrm{pH}=5$, shaking speed $=100 \mathrm{rpm})$.

\section{Adsorption isotherms and kinetics}

Adsorption isotherms show the relations between the amounts of the molecules adsorbed by adsorbent and the amounts of remain molecules in solution when reaching the adsorption equilibrium. Langmuir [39] and Freundlich [40] models are the most used adsorption models in adsorption studies. The Langmuir isotherm is mainly convenient for monolayer adsorption onto a surface, while the Frendlich isotherm characteristically presumes heterogeneous adsorption onto a surface. Separation factor $R_{L}$ helps to determine the applicability of adsorption process, which is expressed by:

$R_{L}=\frac{1}{1+K_{L} C_{i}}$

$R_{L}>1$ for unfavourable adsorption, $0<R_{L}<1$ for favourable adsorption, $R_{L}=0$ for irreversible adsorption, and $R_{L}=1$ for linear adsorption. Moreover, adsorption onto surface is favourable if $1 / n$ value calculated by Freundlich model is between 0 and 1 . The results from Freundlich and Langmuir isotherms drawn for BSA concentrations on EAC at different temperatures are presented in Table 3. When examining correlation constants $\left(R^{2}\right)$ for each temperature value, it is seen that the data of adsorption were compatible with Langmuir isotherm. Especially at 15 and $25{ }^{\circ} \mathrm{C}$, the adsorption capacities for EAC were found quite high. Furthermore, for all temperatures given in Table 3, the fact that the values of $R_{L}$ and $1 / n$ are between 0 and 1 presents favourable for BSA adsorption onto EAC. 
Table 3. Isotherm constants for the adsorption of BSA onto EAC

\begin{tabular}{|c|c|c|c|c|c|c|c|}
\hline \multicolumn{4}{|c|}{ Langmuir Constants } & \multicolumn{3}{c|}{ Freundlich constants } \\
\hline $\begin{array}{c}\text { Temperature } \\
\left({ }^{\circ} \mathrm{C}\right)\end{array}$ & $q_{\max }(\mathrm{mg} / \mathrm{g})$ & $\begin{array}{c}K_{L} \\
(\mathrm{~L} / \mathrm{mg})\end{array}$ & $R^{2}$ & $R_{L}$ & $1 / n$ & $\begin{array}{c}K_{F} \\
(\mathrm{~L} / \mathrm{mg})\end{array}$ & $R^{2}$ \\
\hline 15 & 925.9 & 0.1460 & 0.9950 & 0.0135 & 0.1196 & 476.5 & 0.7071 \\
\hline 25 & 826.4 & 0.4352 & 0.9943 & 0.0046 & 0.1147 & 408.8 & 0.8146 \\
\hline 35 & 369.0 & 0.0093 & 0.9588 & 0.1770 & 0.1105 & 388.9 & 0.8599 \\
\hline
\end{tabular}

At various initial BSA concentrations, pseudo-first-order [41] and pseudo-second-order [42] kinetic models were used to analyze the adsorption process onto EAC. The equations concerning the kinetic models are given in Table 1. By performing the kinetic models, the data obtained experimentally at each BSA concentration are presented in Table 4. When evaluating the values of $R^{2}$, the adsorption process onto EAC was determined to be compatible with pseudo-first-order kinetic model for all BSA concentrations.

Table 4. Kinetic parameters for the adsorption of BSA onto EAC

\begin{tabular}{|c|c|c|c|c|c|c|c|}
\hline & & \multicolumn{3}{|c|}{ Pseudo-first order } & \multicolumn{3}{c|}{ Pseudo-second order } \\
\hline $\begin{array}{c}C_{o} \\
(\mathrm{mg} / \mathrm{L})\end{array}$ & $q_{\exp }$ & $\begin{array}{c}k_{I} \\
\left(\mathrm{~min}^{-1}\right)\end{array}$ & $\begin{array}{c}q_{e} \\
(\mathrm{mg} / \mathrm{g})\end{array}$ & $R^{2}$ & $\begin{array}{c}k_{2} \\
\left(\mathrm{~g} \mathrm{mg}^{-1} \mathrm{~min}^{-1}\right)\end{array}$ & $\begin{array}{c}q_{e} \\
(\mathrm{mg} / \mathrm{g})\end{array}$ & $R^{2}$ \\
\hline 500 & 492.2 & 0.2791 & 495.2 & 0.9785 & 0.0120 & 350.3 & 0.6271 \\
\hline 800 & 698.8 & 0.2545 & 705.2 & 0.9825 & 0.0060 & 622.8 & 0.7421 \\
\hline 1000 & 789.6 & 0.2363 & 798.7 & 0.9645 & 0.0010 & 753.5 & 0.7621 \\
\hline 1200 & 883.9 & 0.2139 & 889.3 & 0.9726 & 0.0008 & 813.5 & 0.7156 \\
\hline 1600 & 890.9 & 0.2062 & 900.5 & 0.9865 & 0.0014 & 824.3 & 0.6824 \\
\hline 2000 & 803.2 & 0.2016 & 814.7 & 0.9688 & 0.0097 & 712.7 & 0.6745 \\
\hline
\end{tabular}

\section{CONCLUSIONS}

The activated carbon prepared from waste Elaeagnus stone using the chemical activation with $\mathrm{ZnCl}_{2}$ has been obtained with a high surface area and proper surface properties for adsorption processes. Based on the experimental results, the adsorption yield decreased with the increase in both temperature and initial BSA concentration. The highest adsorption percentage was determined to be 99.16 at the temperature of $15^{\circ} \mathrm{C}$, BSA concentration of $500 \mathrm{mg} / \mathrm{L}$ and the $\mathrm{pH}$ of 5. The adsorption isotherm and the adsorption kinetics for BSA onto EAC are consistent with Langmuir isotherm model and pseudo-first-order kinetic model, respectively. Given all results in this study, it could be concluded that EAC is a low-cost and efficient adsorbent for BSA adsorption.

\section{REFERENCES}

1. Valdes, H.; Sanchez-Polo, M.; Rivera-Utrilla, J.; Zaror, C.A. Effect of ozone treatment on surface properties of activated carbon. Langmuir 2002, 18, 2111-2116.

2. He, J.X.; Li, S.B.; Shao, W.L.; Wang, D.Y.; Chen, M.Y.; Yin, W.Q.; Wang, W.; Gu, Y.Y.; Zhong, B.L. Activated carbon nanoparticles or methylene blue as tracer during video-assisted thoracic surgery for lung cancer can help pathologist find the detected lymph nodes. J. Surg. Oncol. 2010, 102, 676-682.

3. Gomes, H.T.; Miranda, S.M.; Sampaio, M.J.; Silva, A.M.T.; Faria, J.L. Activated carbons treated with sulfuric acid: Catalysts for catalytic wet peroxide oxidation. Catal. Today 2010, $151,153-158$

4. Walker, G.M.; Weatherley, L.R. Prediction of bisolute dye adsorption isotherms on activated carbon. Process Safety Environ. Protect. 2000, 78, 219-223. 
5. Nayak, A.; Bhushan, B.; Gupta, V.; Sharma, P. Chemically activated carbon from lignocellulosic wastes for heavy metal wastewater remediation: Effect of activation conditions. J. Coll. Inter. Sci. 2017, 493, 228-240.

6. Jiang, Z.X.; Liu, Y.; Sun, X.P.; Tian, F.P.; Sun, F.X.; Liang, C.H.; You, W.S.; Han, C.R.; $\mathrm{Li}, \mathrm{C}$. Activated carbons chemically modified by concentrated $\mathrm{H}_{2} \mathrm{SO}_{4}$ for the adsorption of the pollutants from wastewater and the dibenzothiophene from fuel oils. Langmuir 2003, 19, 731-736.

7. Wang, S.B.; Zhu, Z.H.; Coomes, A.; Haghseresht, F.; Lu, G.Q. The physical and surface chemical characteristics of activated carbons and the adsorption of methylene blue from wastewater. J. Colloid Inter. Sci. 2005, 284, 440-446.

8. Lillo-Rodenas, M.A.; Marco-Lozar, J.P.; Cazorla-Amoros, D.; Linares-Solano, A. Activated carbons prepared by pyrolysis of mixtures of carbon precursor/alkaline hydroxide. J. Anal. Appl. Pyrol. 2007, 80, 166-174.

9. Mohanty, K.; Das, D.; Biswas, M.N. Adsorption of phenol from aqueous solutions using activated carbons prepared from Tectona grandis sawdust by $\mathrm{ZnCl}_{2}$ activation. Chem. Eng. J. 2005, 115, 121-131.

10. Sudaryanto, Y.; Hartono, S.B.; Irawaty, W.; Hindarso, H.; Ismadji, S. High surface area activated carbon prepared from cassava peel by chemical activation. Bioresour. Technol. 2006, 97, 734-739.

11. Heibati, B.; Rodriguez-Couto, S.; Al-Ghouti, M.A.; Asif, M.; Tyagi, I.; Agarwal, S.; Gupta, V.K. Kinetics and thermodynamics of enhanced adsorption of the dye AR 18 using activated carbons prepared from walnut and poplar woods. J. Mol. Liq. 2015, 208, 99-105.

12. Li, Q.; Zhai, J.; Zhang, W.; Wang, M.; Zhou, J.A study on adsorption of $\mathrm{Pb}(\mathrm{II}), \mathrm{Cr}(\mathrm{W})$ and $\mathrm{Cu}(\mathrm{II})$ from aqueous solution by peanut husk. Bull. Chem. Soc. Ethiop. 2008, 22, 19-26.

13. Tesfaw, B.; Chekol, F.; Mehretie, S.; Admassie, S. Adsorption of $\mathrm{Pb}$ (II) ions from aqueous solution using lignin from Hagenia abyssinica. Bull. Chem. Soc. Ethiop. 2016, 30, 473-484.

14. Zhu, X.; Lan, L.; Xiang, N.; Liu, W.; Zhao, Q.; Li, H. Thermodynamic studies on the adsorption of $\mathrm{Cu}^{2+}, \mathrm{Ni}^{2+}$ and $\mathrm{Cd}^{2+}$ on to amine-modified bentonite. Bull. Chem. Soc. Ethiop. 2016, 30, 357-367.

15. Üner, O.; Geçgel, Ü.; Bayrak, Y. Adsorption of methylene blue by an efficient activated carbon prepared from Citrullus lanatus rind: Kinetic, isotherm, thermodynamic, and mechanism analysis. Water Air Soil Pollut. 2016, 227: 247. DOI: 10.1007/s11270-0162949-1.

16. Geçgel, Ü.; Kocabıyık, B.; Üner, O. Adsorptive removal of methylene blue from aqueous solution by the activated carbon obtained from the fruit of Catalpa bignonioides. Water Air Soil Pollut. 2015, 226: 238. DOI: 10.1007/s11270-015-2513-4.

17. Üner, O.; Geçgel, Ü.; Kolancilar, H.; Bayrak, Y. Adsorptive removal of rhodamine B with activated carbon obtained from okra wastes. Chem. Eng. Commun. 2017, 204, 772-783.

18. Berrios, M.; Martin, M.A.; Martin, A. Treatment of pollutants in wastewater: adsorption of methylene blue onto olive-based activated carbon. J. Ind. Eng. Chem. 2012, 18, 780-784.

19. Aygün, A.; Yenisoy-Karakaş, S.; Duman, I. Production of granular activated carbon from fruit stones and nutshells and evaluation of their physical, chemical and adsorption properties. Micropor. Mesopor. Mat. 2003, 66, 189-195.

20. Geçgel, Ü.; Kolancilar, H. Adsorption of remazol brilliant blue R on activated carbon prepared from a pine cone. Nat. Product. Res. 2012, 26, 659-664.

21. Kannan, N.; Sundaram, M.M. Kinetics and mechanism of removal of methylene blue by adsorption on various carbons - A comparative study. Dyes Pigm. 2001, 51, 25-40.

22. Geçgel, Ü.; Özcan, G.; Gürpınar, G.Ç. Removal of methylene blue from aqueous solution by activated carbon prepared from pea shells (Pisum sativum). J. Chem. 2013, 2013, Article ID 614083, DOI: 10.1155/2013/614083. 
23. Attia, A.A.; Girgis, B.S.; Khedr, S. Capacity of activated carbon derived from pistachio shells by $\mathrm{H}_{3} \mathrm{PO}_{4}$ in the removal of dyes and phenolics. J. Chem. Technol. Biotech. 2003, 78, 611-619.

24. Ghaedi, A.M.; Ghaedi, M.; Vafaei, A.; Iravani, N.; Keshavarz, M.; Rad, M.; Tyagi, I.; Agarwal, S.; Gupta, V.K. Adsorption of copper(II) using modified activated carbon prepared from Pomegranate wood: Optimization by bee algorithm and response surface methodology. J. Mol. Liq. 2015, 206, 195-206.

25. Brandes, N.; Welzel, P.B.; Werner, C.; Kroh, L.W. Adsorption-induced conformational changes of proteins onto ceramic particles: differential scanning calorimetry and FTIR analysis. J. Coll. Inter. Sci. 2006, 299, 56-69.

26. Carter, D.C.; Ho, J.X. Structure of serum albumin. Adv. Protein Chem. 1994, 45, 153-203.

27. Hu, T.; Su, Z. A solid phase adsorption method for preparation of bovine serum albuminbovine hemoglobin conjugate. J. Bio-Technol. 2003, 100, 267-275.

28. Figgie, J.; Rossing, T.H.; Fencl, V. The role of serum proteins in acid-base equilibria. $J$. Lab. Clin. Med. 1991, 117, 453-467.

29. Sheveleva, I.V.; Voit, A.V.; Zemskova, L.A. Adsorption of protein by modified carbon fibres. Chem. Sustainable Dev. 2006, 14, 295-299.

30. Milonjić, S.K.; Ruvarac, A.L.; Šušić, M.V. The heat of immersion of natural magnetite in aqueous solutions. Thermochim. Acta 1975, 11, 261-266.

31. Hesas, R.H.; Niya, A.A.; Daud, W.M.A.W.; Sahu, J.N. Preparation of granular activated carbon from oil palm shell by microwave-induced chemical activation: Optimisation using surface response methodology. Chem. Eng. Res. Des. 2013, 91, 2447-2456.

32. Yang, J.; Qiu, K. Preparation of activated carbons from walnut shells via vacuum chemical activation and their application for methylene blue removal. Chem. Eng. J. 2010, 165, 209217.

33. Yu, L.; Luo, Y-M. The adsorption mechanism of anionic and cationic dyes by Jerusalem artichoke stalk-based mesoporous activated carbon. J. Environ. Chem. Eng. 2014, 2, 220229.

34. Sun, Y.; Webley, P.A. Preparation of activated carbons from corncob with large specific surface area by a variety of chemical activators and their application in gas storage. Chem. Eng. J. 2010, 162, 883-892.

35. Dağdelen, S.; Acemioğlu, B.; Baran, E.; Koçer, O. Removal of remazol brilliant blue R from aqueous solution by pirina pretreated with nitric acid and commercial activated carbon. Water Air Soil. Pollut. 2014, 225, 1899.

36. Martins, A.C.; Pezoti, O.; Cazetta, A.L.; Bedin, K.C.; Yamazaki, D.A.S.; Bandoch, G.F.G.; Asefa, T.; Visentainer, J.V.; Almeida, V.C. Removal of tetracycline by $\mathrm{NaOH}$-activated carbon produced from macadamia nut shells: kinetic and equilibrium studies. Chem. Eng. J. 2015, 260, 291-299.

37. Maleki, M.S.; Moradi, O.; Tahmasebi, S. Adsorption of albumin by gold nanoparticles: Equilibrium and thermodynamics studies. Arab. J. Chem. 2017, 10, S491-S502.

38. Bhattacharya, A.K.; Naiye, T.K.; Mandal, S.N.; Das, S.K. Adsorption, kinetics and equilibrium studies on removal of $\mathrm{Cr}(\mathrm{VI})$ from aqueous solutions using different low-cost adsorbents. J. Chem. Eng. 2008, 137, 529-541.

39. Langmuir, I. J. Am. Chem. Soc. 1916, 38, 2221-2295.

40. Freundlich, H.M.F. Over the adsorption in solution. Z. Phys. Chem. 1906, 57, 385-471.

41. Lagergren, S.; Svenska, B.K. About the theory of so-called adsorption of soluble substances. Handlingar 1898, 24, 1-39.

42. Ho, Y.S.; McKay, G. Pseudo-second order model for sorption processes. Process Biochem. 1999, 34, 451-465. 